\title{
IMPLEMENTASI PEMBELAJARAN KREATIF SENI RUPA ANAK PAUD BERBASIS DARING
}

\author{
Devi Vionitta Wibowo, Aninditya Sri Nugraheni \\ Fakultas Ilmu Tarbiyah dan Keguruan UIN Sunan Kalijaga Yogyakarta \\ E-mail: vionittadevi@gmail.com, aninditya.nugraheni@uin-suka.ac.id
}

\begin{abstract}
Abstrak
Kreativitas menjadi salah satu fokus utama pendidikan abad 21. Karena itu, penelitian ini mencoba menganalisis bagaimana implementasi pembelajaran kreatif seni rupa pada tingkat PAUD secara daring. Metode penelitian berbentuk kualitatif studi kasus pada Lembaga PAUD Masyithoh Rembang. Hasil penelitian menyatakan bahwa pembelajaran kreatif seni rupa dirangkum dalam silabus kurikulum darurat milik lembaga yang dibuat melalui program harian yang pelaksanaanya melalui Facebook, Youtube, Video Call, dan WhatsApp. Kegiatan seni rupa dua dimensi berupa kegiatan melukis serta seni tiga dimensi yang berupa karya membuat wayang binatang, mainan kacamata, gambar ikan dari barang bekas, kolase, serta bentuk rumah dari plastisin. Evaluasi yang didapat adalah anak dapat mengikuti kegiatan pembelajaran dengan baik dan melalui kegiatan ini dapat meningkatkan aspek perkembangan anak yang terdiri dari kognitif, sensorimotorik, bahasa, emosional serta bakat dan kreativitas anak.
\end{abstract}

Kata Kunci: Pembelajaran, Kreatif, Seni Rupa, PAUD, Daring

\section{IMPLEMENTATION OF ONLINE-BASED PAUD CHILDREN'S CREATIVE ARTS LEARNING}

\begin{abstract}
Creativity is one of the main focuses of $21^{\text {st }}$-century education. Therefore, this study tries to analyze how the implementation of fine arts online creative learning at PAUD level. The research method is in the form of a qualitative case study at the PAUD Masyithoh Institute, Rembang. The results of the study stated that creative art learning was summarized in the institution's emergency curriculum syllabus, which was made through daily programs whose implementation was through Facebook, Youtube, Video Call, and WhatsApp. Two-dimensional art activities in the form of painting activities and three-dimensional art in the form of making animal puppets, glasses, toys, fish pictures from used goods, collages, and the shape of houses from plasticine. The evaluation obtained is that children can participate in learning activities well. Through these activities can improve aspects of child development consisting of cognitive, sensorimotor, language, emotional, and children's talents and creativity..
\end{abstract}

Keywords: Learning, Creative, Fine Art, PAUD, Online 


\section{PENDAHULUAN}

Adanya suatu kebijakan baru dari pemerintah terkait pelaksanaan pembelajaran daring yang diterapkan dari rumah membuat para guru, anak dan orangtua harus menyiapkan mentalitas, kreativitas, dan beradaptasi terhadap penggunaan media teknologi sebagai sumber belajar anak (Susanto, 2020). Adapun sistematika pembelajaran daring antara lain melalui Learning Management System (LMS) dan media sosial, seperti media zoom meeting, youtube, dan whatsApp group. Selain dari pada itu, adanya sistem pembelajaran daring hendaknya diterapkan dengan tidak memberatkan anak, sesuai dengan kebutuhan anak, dan dapat menumbuhkan motivasi dalam belajar meskipun pembelajaran tidak dilakukan secara bertatap muka (Menteri Pendidikan \& Kebudayaan RI, 2020, p.1). Sistematika yang terlampir dalam surat edaran pemerintah tersebut membuat para guru harus mengimplementasikan kegiatan yang menarik perhatian anak agar anak bisa trampil, kreatif serta dapat menumbuhkan dan mengembangkan aspek perkembangan anak. Penelitian mengungkapkan bahwa pembelajaran yang kreatif dapat menumbuhkan emotional baik bagi anak sejak dini dengan merasakan senang, gembira dan dan tidak bosan saat pembelajaran dimulai (Hidayah, 2020, p. 269).

Kegiatan pembelajaran yang menarik, menyenangkan dan kreatif dapat diaplikasikan kepada anak-anak. Hal ini mengingat bahwa adanya problematika pendidikan anak usia dini selama masa pembelajaran daring. Dampak yang ada adalah banyak anak yang merasa bosan dikarenakan pembelajaran bersifat monoton, dan kurang adanya dorongan dari orangtua untuk memberikan bimbingan yang kreatif bagi anak saat implementasi pembelajaran dari rumah (Betiani, 2020). Timbulnya problematika tersebut, maka para orangtua dan guru hendaknya bekerjasama untuk membantu peningkatan pembelajaran anak secara kreatif dan inovatif agar anak tidak bosan saat belajar dan bermain secara online. Peran orangtua dalam meningkatkan pembelajaran yang kreatif adalah melalui pendampingan belajar dan memfasilitasi kebutuhan anak (Yulianingsih, 2021). Sebuah penelitian mengungkapkan bahwa ketika hendak melaksanakan pembelajaran daring yang kreatif serta membuat anak nyaman dan senang, maka guru dan orangtua harus selalu menjadi pendamping, fasilitator, adanya kerjasama antara dua belah pihak, serta adanya bimbingan terkait pembelajaran yang akan dilakukan (Khadijah \& Gusman, 2020).

Adapun yang dimaksud dengan pembelajaran yang bersifat kreatif adalah sebuah pembelajaran bagi anak usia dini yang ditawarkan melalui metode, strategi, dan berbagai kegiatan yang menyenangkan bagi anak. Hal ini berpengaruh pada emosional anak. Anak akan tertarik, tidak bosan dan bersemangat saat pembelajaran (Fadlillah, 2014, p. 6). Kegiatan yang diberikan kepada anak hendaknya bersifat kreatif dan inovatif agar dapat meningkatkan pola berfikir kreatif kepada anak dan menambah wawasan keingintahuan anak (Astuti et al., 2021). Anak juga belajar perihal pendidikan estetika melalui pembelajaran yang kreatif. Adanya hal tersebut maka, anak menjadi subyek utama dalam pengimplementasian pembelajaran ini. Arti dari subyek utama pada diri anak adalah guru menganjurkan anak untuk berfikir, berkreasi, berimajinasi dan bereksplorasi sesuai dengan bimbingan dan arahan guru. Hal ini diimplementasikan kepada anak berdasarkan tahap-tahap perkembangan anak (Rapisa, 2019, p. 143). Teori-teori tersebut menjelaskan bahwa pembelajaran yang kreatif dan inovatif bagi anak usia dini sangatlah penting diaplikasikan kepada anak usia dini khususnya pada pembelajaran daring di masa pandemi covid 19.

Adanya hal tersebut, maka salah satu pembelajaran yang bersifat kreatif, inovatif dan menyenangkan bagi anak adalah pembel- 
ajaran kreatif seni rupa bagi anak usia dini. Pembelajaran seni rupa merupakan salah satu pembelajaran seni bagi anak usia dini yang difokuskan pada pengembangan aspek seni, imajinasi, kreativitas, sensorimotorik serta pengembangan nilai-nilai kemanusiaan dan kehidupan anak (Fakhruddin, 2019, p. 294). Sebuah penelitian menyatakan bahwa pembelajaran seni rupa bagi anak usia dini memiliki tujuan sebagai dasar untuk meningkatkan dan mengembangkan imajinasi anak. Ketika anak berkreasi, maka secara tidak langsung belajar akan menciptakan karya sendiri dengan bantuan sensorimotoriknya. Anak akan belajar mengenai tata cara menghargai dan menyenangi karya yang diciptakannya sendiri (Yuningsih, 2019, p. 6).

Penelitian terdahulu mengungkapkan bahwa kegiatan seni kreativitas bagi anak usia dini dengan contoh kegiatan bermain warna melalui teknik melukis dan fingger painting dapat meningkatkan imajinasi, emosional, kognitif, bahasa, seni bagi anak sejak dini. Melalui kegiatan seni ini anak dapat bereksplorasi melalui macam-macam warna (Wibowo \& Suyadi, 2020). Kegiatan kreativitas seni rupa juga dapat mempengaruhi tingkat psikologis anak dengan bantuan gambar visual dan nilai estetik yang dihasilkan anak. Adanya gambar hasil karya anak, maka anak akan belajar akan keindahan estetika dari gambar yang dihasilkan (I.Bagus, 2020). Selain hal tersebut, implementasi kegiatan seni rupa bagi anak juga dapat membantu mengkoordinir otot-otot motorik halus anak, seperti kegiatan membentuk, melipat dan menggunting. Kegiatan seni rupa ini dapat dikembangkan dalam kegiatan seni rupa dua dimensi dan tiga dimensi sehingga berfungsi sebagai strategi pembelajaran agar otot-otot anak dapat elastis dan tidak kaku saat digerakkan. Ini merupakan sebuah olahraga sederhana untuk pertumbuhan dan perkembangan otot pada bagian tangan anak (Sarasehan, 2020).
Melalui beberapa penelitian tersebut penulis tertarik ingin meneliti mengenai konsep pembelajaran seni rupa bagi anak usia dini yang dilaksanakan di lembaga PAUD di Rembang. Lembaga PAUD merupakan salah satu lembaga pendidikan bagi anak usia dini yang berfungsi sebagai dasar pembentukan karakteristik, emosional, imajinasi, intelektual, dan potensi anak usia dini agar mereka dapat mempersiapkan diri menuju jenjang yang lebih tinggi yaitu jenjang SD. Salah satu lembaga PAUD yang mengimplementasikan pembelajaran seni rupa bagi anak usia dini adalah RA Masyithoh Rembang. Ibu Kepala Sekolah RA Masyithoh menyatakan bahwa pengimplementasian pembelajaran seni rupa bagi anak sangatlah dianjurkan. Hal ini dikarenakan adanya sistem pembelajaran daring secara online yang mengharuskan para guru untuk mengkreasikan pembelajaran secara menarik bagi anak.

Adanya beberapa faktor diatas, maka peneliti tertarik untuk menganalisis konsep pembelajaran seni rupa secara daring bagi anak usia dini yang diterapkan di RA Masyithoh Rembang. Analasis Konsep penelitian ini meliputi analisis macam-macam pembelajaran seni rupa anak, prosedur pengimplementasiannya, serta evaluasi yang didapat dari adanya pembelajaran seni rupa bagi anak usia dini selama masa pandemi. Adapun tujuannya adalah agar artikel ini dapat memberikan kontribusi bagi para peneliti, mahasiswa, maupun dosen agar selalu meningkatkan pendidikan kreativitas anak melalui berbagai macam karya tulis ilmiah yang bertemakan seni anak usia dini. Para pendidik khususnya guru dan orangtua harus megajarkan anak melalui berbagai macam kreativitas seni rupa yang menyenangkan bagi anak agar tercapainya perkembangan motorik, kognitif, emosional, maupun kreativitas seni anak. Harapan dari adanya artikel ini adalah untuk membangkitkan semangat para pendidik agar selalu memberikan pendidikan yang terbaik bagi anak khususnya pendidikan seni saat pembelajaran daring dilakukan. 


\section{METODE}

Penelitian dalam artikel ini menggunakan jenis penelitian kualitatif berpendekatan studi kasus. Pendekatan ini digunakan dalam menganalisis peristiwa atau kegiatan yang dianggap menarik sehingga menghasilkan peningkatan dalam pengimplementasiannya (Sugiyono, 2014, p. 23-2). Peneliti menganalisis konsep pembelajaran kreatif seni rupa yang diaplikasikan oleh pendidik dan anak didik ketika pembelajaran daring di lembaga pendidikan RA Masyithoh Rembang. Peneliti mewawancarai kepala sekolah dan para guru wali kelas sebagai narasumber utama. Peneliti juga menganalisis dokumentasi berupa kurikulum darurat milik lembaga RA sebagai pedoman dalam pembelajaran di masa pandemi. Adapun dokumentasi digunakan peneliti sebagai data tambahan yag berbentuk gambar kegiatan kreativitas seni rupa yang dilakukan anak selama pembelajaran daring.

Penelitian ini menggunakan beberapa prosedur dalam penerapannya. Pertama-tama peneliti datang ke lokasi penelitian di pagi hari, kemudian melakukan interview kepada kepala sekolah dan empat guru RA Masyithoh sebagai tindakan pengumpulan data. Setelah dilaksanakannya interview kepada narasumber utama, peneliti melakukan analisis dokumentasi, berupa analisis pedoman kurikulum pembelajaran yang digunakan saat pandemi . Peneliti mengumpulkan dokumentasi berupa foto dan video dari media sosial milik lembaga RA dan dari dokumentasi guru RA. Peneliti juga melakukan observasi berupa pengamatan saat kegiatan parenting antara guru, orangtua dan anak di sekolah.

\section{HASIL DAN PEMBAHASAN \\ Hasil \\ Perencanaan Kegiatan Pembelajaran kre- atif Seni Rupa Anak PAUD}

Perencanaan pembejaran kreativitas seni rupa di RA Masyithoh Rembang berpedoman pada penggunaan kurikulum darurat saat pandemi covid 19. Adanya implementasi kurikulum darurat covid 19 yang digunakan pihak RA dalam penerapan pembelajaran seni anak dapat memudahkan guru dalam merancang tingkat pembelajaran seni kreativitas anak. Adapun tujuan perencanaan pembelajaran kreatif seni rupa RA Masyithoh Rembang adalah sebagai dasar bagi anak usia dini untuk mengembangkan pribadi anak sebagai peribadi yang memiliki dasar pengembangan kreativitas dan estetika dengan menampilkan dan membuat hasil karya dengan bimbingan orangtua dan direkam di depan orangtua. Selain hal tersebut, implementasi pembelajaran seni rupa PAUD saat pandemi dapat bertujuan sebagai pengembang dan pengendalian diri anak agar anak dapat menghargai pribadi, dan hasil karya yang diciptakannya sendiri.

Perencanaan pembelajaran seni di RA Masyithoh Rembang saat pandemi berpedoman pada penyusunan PROTA (Program Tahunan), PROMES (Program Semester), RPPM (Rencana Pelaksanaan Pembelajaran Mingguan) dan RPPH (Rencana Pelaksanaan Pembelajaran Harian). Adapun Program Tahunan dan Program Semester bagi pembelajaran seni anak usia dini di lembaga RA ini diterapkan melalui tema-tema yang disajikan dalam bentuk yang inovatif dan menarik. Kreativitas seni di RA Masyithoh Rembang diterapkan melalui pembelajaran daring. Perencanaannya ada pada penggunaan media sosial seperti Youtube, Facebook, Vidio Call dan WhatsApp Group. Para guru antuasis dalam menjalankan pembelajaran seni melalui daring tanpa bertatap muka secara langsung. Pembelajaran dilangsungkan mulai dari bangun tidur sampai waktu menjelang makan siang bergantung pada program harian sekolah. Anak memilih kegiatan yang mereka sukai terlebih dahulu. Orangtua harus mendapingi anak disetiap kegiatan pembelajaran.

Selain perencanaan penyusunan Program Tahunan dan Program Semester, adanya implementasi perencanan pembelajaran dalam 

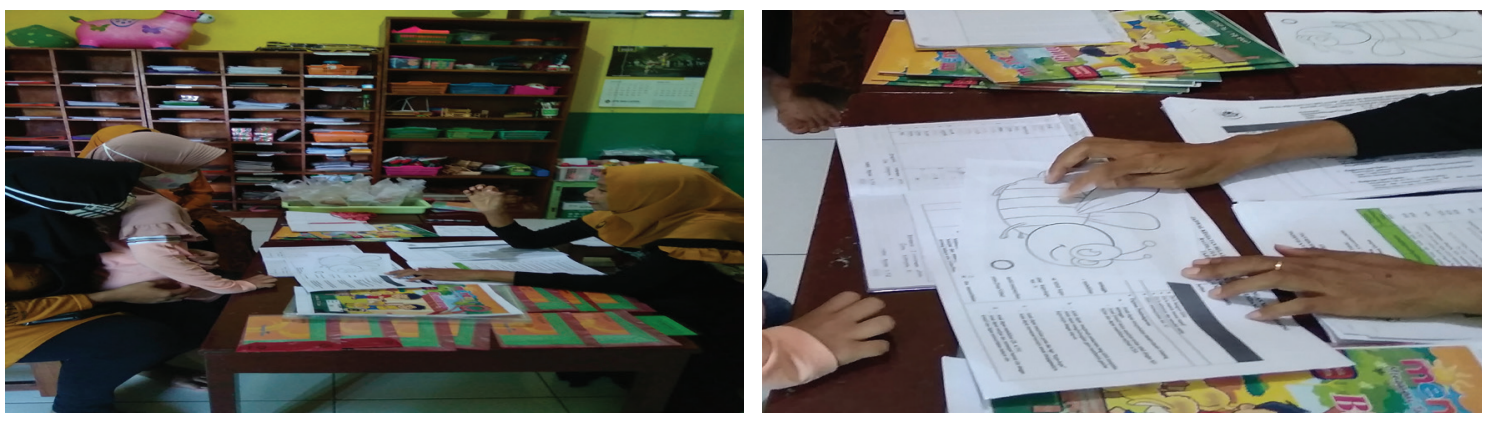

Gambar 1. Pembagian media seni rupa dalam pembelajaran kolase lebah

bentuk penyusunan RPPM dan RPPH untuk memperlancar proses pembelajaran pembelajaran kreatif seni pada anak. Adapun pembelajaran seni berdasarkan panduan RPPM dalam kurikulum darurat dapat diimplementasikan melalui kegiatan pembuatan karya seni kolase dari barang bekas, kegiatan mewarnai dan melukis, menciptakan karya dengan plastisin. Para guru memilih kegiatan kreativitas seni tersebut dikarenakan agar dapat membangkitkan semangat anak dalam berkreasi walaupun pembelajaran dilakukan tidak bertatap muka. Perencanaan pembelajaran berdasarkan rancangan mingguan dan harian tersebut dilaksanakan guru sesuai dengan tema pada tiap mingguannya. Ibu Marliyah selaku kepala sekolah RA Masyithoh menyarankan agar setiap rancangan pembelajaran kreatif seni rupa pada tiap mingguan dan harian harus berdasarkan tema. Hal ini diterapkan agar anak dapat menciptakan karya seni yang estetis sesuai dengan alat dan bahan dari rumah. Adanya perencanaan ini maka, aspek perkembangan seni pada anak usia dini dapat terealisasikan dengan baik saat pandemi covid.

Ketika hendak melaksanakan pembelajaran seni, maka para orangtua dan anak ikut hadir ke sekolah untuk mengambil media pembelajaran. Kegiatan ini dilaksanakan tiap seminggu sekali. Adapun prosedurnya adalah jika anak tingkat $\mathrm{A}$ maka jam pelaksanaan pukul 08.00-10.00 WIB. Jika anak B maka jam pelaksanaan kegiatan pengambilan media seni pukul 10.00-12.00 WIB. Ketika kegiatan ini, guru menjelaskan prosedur pengerjaan kegiatan seni dalam media yang telah dibuat. Kegiatan ini dilakukan menggunakan protokol kesehatan. Selain guru memberikan media pembelajaran seni pada anak dan orangtua, guru memberikan arahan agar hasil karya anak dikumpulkan pada hari dimana pemberian media berlangsung.

\section{Implementasi Pelaksanaan Kegiatan Pem- belajaran kreatif Seni Rupa pada PAUD}

Pelaksanaan kegiatan pembelajaran seni bagi anak usia dini di RA Masyithoh Rembang berdasarkan prosedur kurikulum darurat milik RA Masyithoh Rembang yaitu mewajibkan implementasi pembelajaran melalui daring, yaitu pembelajaran jarak jauh. Implementasi belajar kreatif anak terprogram setiap hariannya. Adapun pembelajaran seni yang dilakukan anak dalam rancangan pembelajaran harian meliputi kegiatan ekstra mewarnai pada hari Rabu yang dipandu oleh Kak Yono, kegiatan kolase domba, melipat ulat dari kertas origami, membuat rumah dari plasisin, membut kacamata dari barang bekas. Adapun yang dilakukan guru dalam mengimplementasi pembelaaran kreativitas seni dapat dilakukan dengan kegiatan membuat kreasi ikan dengan tutup botol. Berikut contoh gambar implementasi kegiatan kreasi seni rupa anak membuat wayang kambing 

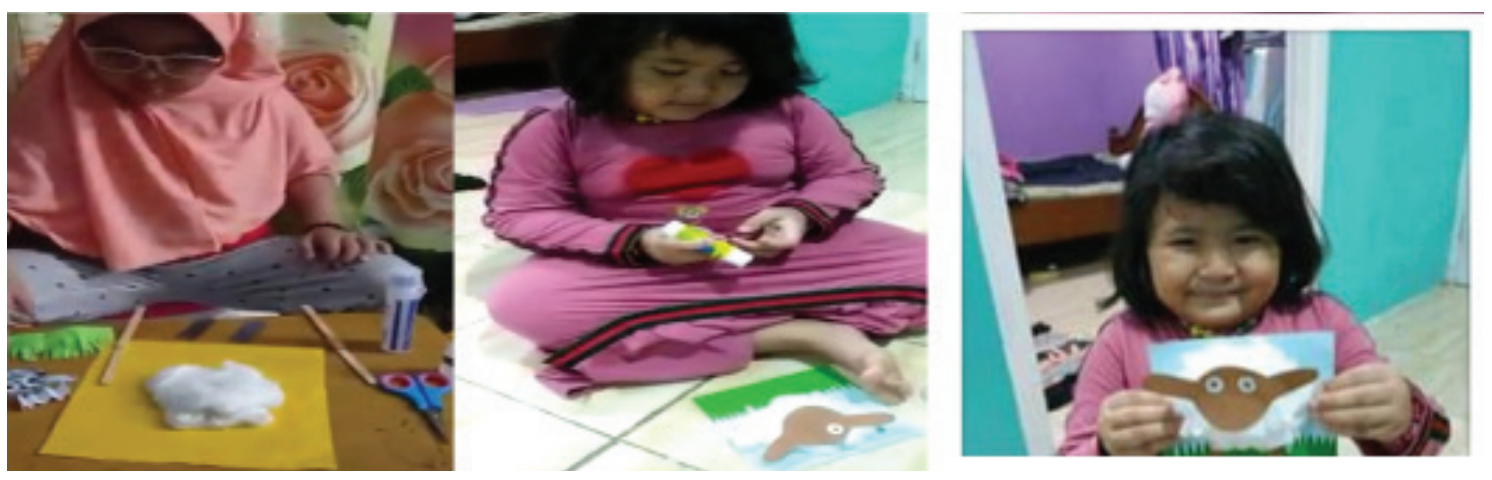

\section{Gambar 2. Implementasi pembuatan kreativitas seni wayang binatang dari rumah}

dari kapas saat pembelajaran daring di hari Selasa tanggal 3 November 2020 di kelas B3.

Adapun penjelasan pembuatan kreativitas membuat wayang kambing dari kapas pada gambar di atas adalah anak dan orangtua mempersiapkan bahan-bahan kreasi seni terlebih dahulu. Adapun bahan dan alatnya adalah kapas putih sebagai kolase dan badan domba, kertas origami yang sudah dipotong dan dibentuk oleh pihak guru, dua stik es krim, dan kertas bufalo atau kertas karton sebagai bahan dasar untuk peletakkan kolase domba. Adapun alat yang perlu dipersiapkan adalah gunting dan lem. Cara membuatnya adalah anak-anak diharapkan untuk menempelkan kapas milik mereka sendiri diatas kertas bufalo yang sudah disediakan. Orangtua mendampingi anak agar dapat mengimplementasikannya dengan baik. Setelah kapas tertempel, anak merapikannya dan menempelkan bentuk kepala kambing beserta mata kambing yang sudah disediakan guru. Setelah itu, anak-anak diminta untuk menggunting pola bentuk rumput yang sudah disediakan guru lalu ditempelkan sebagai rumput domba. Jika pola kolase sudah tertata dengan rapi maka tugas anak selanjutnya adalah menempelkan dua batang es krim di bawah gambar kambing agar dapat digunakan seba- gai tangkai wayang yang berguna untuk pegangan penggerak ketika menceritakan cerita atau dongeng yang bertemakan binatang kambing

Kegiatan tersebut dilakukan melalui pembelajaran daring. Para orangtua mendampingi anak-anak dalam membuat karya dengan dampingan yang baik. Selain itu para orangtua mendokumentasikan kegiatan anak dengan mengambil foto kegiatan anak dalam melakukan kreasi. Setelah kegiatan terealiasasikan, para orangtua mengirimkan hasil dokumentasi tersebut kepada guru melalui group WhatsApp. Setelah dikirimkan, tugas guru adalah mengunggah hasil gambar dan video anak ke media sosial Facebook RA Masithoh Rembang. Selain daripada itu, para guru juga ikut berpartisipasi memberikan arahan pembelajaran kreasi seni melalui media youtube agar anak dan orangtua dapat melihat dengan seksama sehingga dapat diterapkan oleh anak dengan senang. Adapun bahan dan alat untuk membuat kreasi seni rupa ikan dari tutup botol yang diperagakan guru yaitu tutup botol, spidol, lem, gunting dan kertas lipat. Teknik pembuatannya dikirimkan melalui media sosial youtube RA Masyithoh dengan akun youtube Wasiah Minhatir salah satu guru di RA Masyithoh 

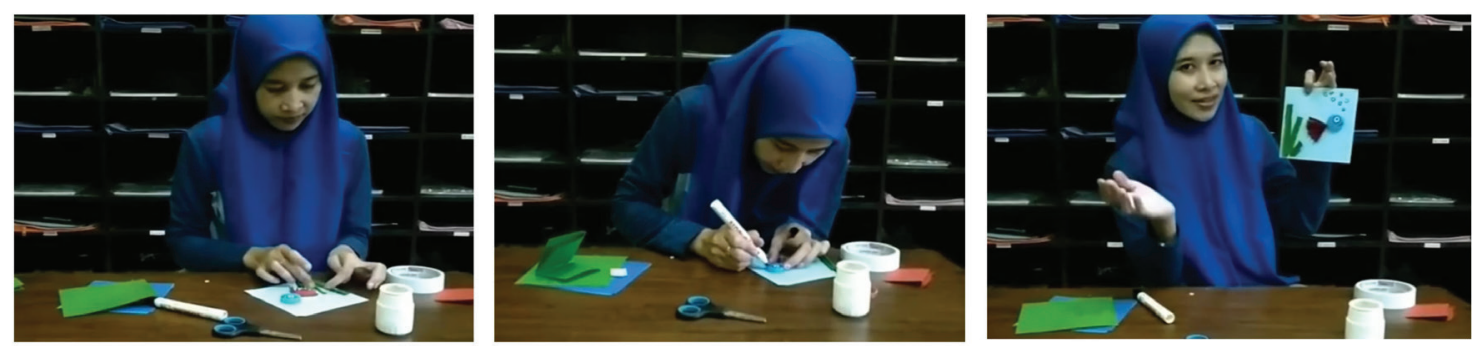

Gambar 3. Implementasi Kegiatan Pembelajaran kreasi seni rupa ikan dari tutup botol

Adapun cara membuat kreasi seni rupa bentuk ikan dari tutup botol yang diperagakan oleh salah satu guru RA Masyitoh pada gambar diatas adalah pertama-tama menyiapkan bahan dan alat untuk membuatnya. Adapun alat yang digunakan adalah tutup botol, spidol, lem, gunting dan kertas lipat. Cara pembuatannya adalah sediakan bahan dasarnya terlebih dahulu, yaitu satu tutup botol kecil ataupun besar sesuai selera dan beberapa kertas origami. Langkah pertama membuat pola ikan di atas kerta origami yang berwarna dasar biru muda. Langkah kedua guru melipat kertas origami menjadi seperti rumput kemudian ditempelkan diatas kertas origami yag berwarna biru. Langkah selanjutnya adalah guru menjiplak atau mencetak bentuk bulat dari tutup botol ditas kertas origami dengan spidol. Setelah dicetak bulat maka guru menggunting pola bulat dengan menggunakan gunting. Langkah selanjutnya adalah menempelkan hasil guntinggan di atas tutup botol. Setelah tertata rapi, maka tugas guru adalah menempelkan tutup botol yang sudah dilapisi kertas origami diatas kertas origami yang berwarna biru. Langkah selanjutnya guru memberikan bentuk mata dengan mnggunakan spidol. Langkah selanjutnya guru membentuk sirp ikan dengan menggunakan kertas origami selanjutnya ditempelkan sebagai sirip ikan. Setelah pola ikan dan rumput sudah tertata rapi, kini guru menggambar pola bulat-bulat kecil sebagai gambar gelombang air yang menggenang.
Selain kegiatan tersebut, kegiatan seni kreatif yang wajib dilakukan anak adalah kegiatan ekstrakulikuler mewarnai. Kegiatan esktrakulikuler ini wajib diterapkan sebagai pengembangan aspek seni anak dalam mengenal warna dan melukis gambar. Kegiatan ekstra seni lukis diwajibkan bagi seluruh anak di RA Masyithoh Rembang baik dari tingkat A dan B. Prosedurnya adalah para guru memberikan media pembelajaran setiap hari sabtu. Setelah media didapat oleh anak, maka tugas anak adalah memberikan warna sesuai dengan keinginannya sendiri. Para orangtua mendampingi anak saat mewarnai gambar. Kegiatan pembelajaran dilaksanakan dari rumah masing-masing. Setelah kegiatan mewarnai selesai maka hasil karya anak dikumpulkan saat pengambilan media di hari Sabtu. Adapun penilaiannya adalah melalui guru wali kelas dan tutor mewarnai. Kegitan ini diimplementsikan berdasarkan tema pada setiap minggu. Gambar 4 menunjukkan implementasi pelaksanaan kegiatan esktra mewarnai gambar anak RA Masyithoh Rembang yang diupload di akun Facebook lembaga yang bernama akun@RA Masyithoh Rembang.

Bentuk kegiatan yang diberikan kepada anak-anak sangatlah banyak dan kreatif. Selain adanya kegiatan kreatif membuat wayang dari kapas, kreasi ikan dari tutup botol yang diperagakan oleh guru, dan kegiatan ekstrakulikuler mewarnai dan melukis, anakanak juga berkreasi membuat bentuk ulat dari kertas origami, membuat bentuk kacamata dari botol air mineral bekas, dan membuat 

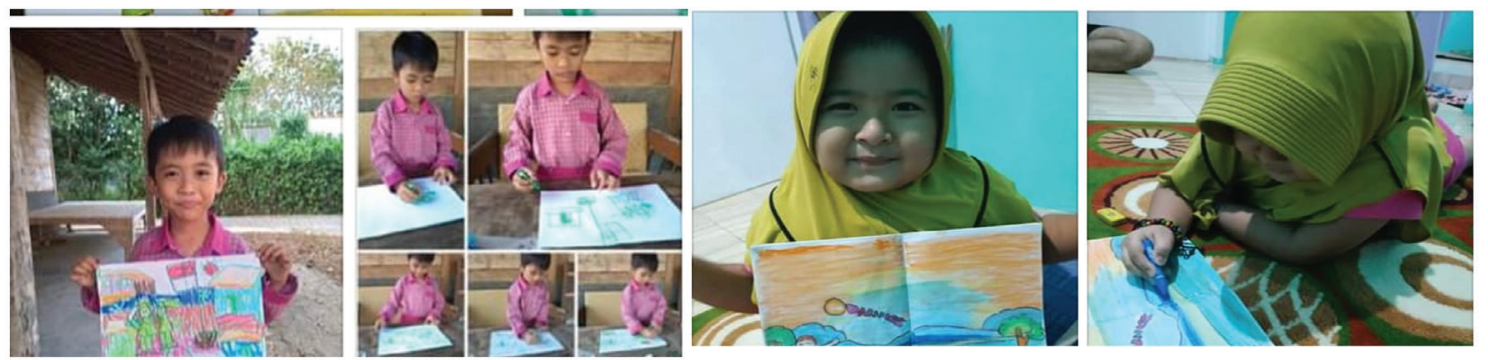

\section{Gambar 4 Implementasi Pembelajaran Esktra Mewarnai dan Menggambar RA Masyithoh}

bentuk rumah dari plastisin. Hasil karya anak diunggah oleh guru-guru dalam media sosial facebook agar para orangtua dan anak dapat melihat hasil karya yang diciptakannya. Adapun karya yang dikirimkan di Facebook adalah karya anak pilihan yang memiliki kategori bagus dan menarik. Berikut gambaran hasil apresiasi seni rupa anak yang telah diunggah guru ke dalam media sosial Facebook dengan akun RA Masyithoh Rembang.

Gambar 5 menceritakan beberapa anak yang memiliki hasil karya kreativitas terbaik di RA Masyithoh Rembang. Pembelajaran dilaksanakan melalui daring, yaitu melalui rekaman video dan foto anak. Apreasiasi gambar di atas adalah anak-anak yang berkreasi kolase lebah memakai biji-bijian, membuat bentuk ulat dari kertas origami, membuat bentuk kacamata dari botol air mineral bekas, membentuk gambar rumah dari plastisin, dan mewarai serta melipat baju dari kertas origami. Sebelum anak-anak berkreasi, maka pendidik mengarahkan agar para orangtua ikut membimbing dalam pembuatan karya seni. Kegiatan tersebut dilaksaksanakan saat pengambilan media pada hari Sabtu. Tugas orangtua adalah membimbing anak-anak untuk membuat kreasi sendiri berdasarkan arahan guru.

\section{Implementasi Evaluasi Kegiatan Pembel- ajaran kreatif Seni Rupa PAUD}

Adanya hasil evaluasi pembelajaran seni rupa bagi anak di RA Masyithoh berupa kendala guru dalam implementasi kegiatan seni rupa anak. Para guru tidak dapat mendampingi anak sesara langsung ketika berkreasi. Hal tersebut tidak mengurangi prestasi pada kreativitas seni anak usia dini. Orang tua ikut berperan aktif dalam mendampingi anak belajar berkreasi dari rumah. Timbal baliknya adalah adanya prestasi karya seni anak yang meningkat dan bagus walaupun para guru tidak dapat mendampingi anak saat berkreasi.

Kegiatan penilaian yang diterapkan pada pembelajaran kreatif seni rupa anak usia dini di
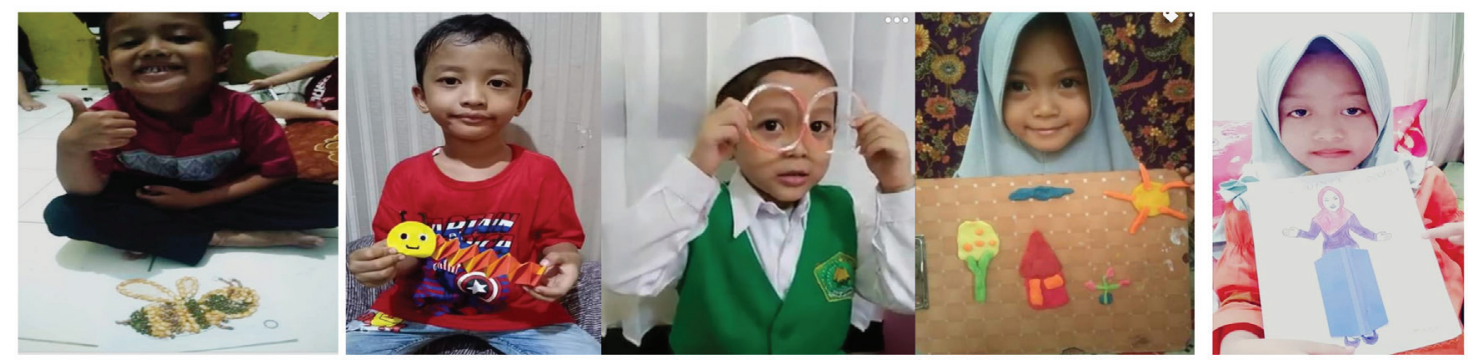

Gambar 5. Apresiasi hasil Karya seni anak RA Masyithoh Rembang Selama Pandemi 
RA Masyithoh Rembang berdasarkan hasil karya yang dikumpulkan oleh para orang tua setiap hari Sabtu ketika pelaksanaan kegiatan pengambilan media untuk satu minggu ke depannya. Adapun penilaian dilakukan oleh guru wali kelas dan asisten wali kelas agar penilaian dapat berjalan dengan lancar. Penilaian diterapkan sesuai dengan hasil karya dan capaian perkembangan anak. Adapun kategori penilaian yang dilakukan guru terdiri dari empat kategori. Kategori tersebut terbilang kurang baik dan sangat baik. Jika anak yang memiliki kreativitas seni rupa yang baik maka para guru dapat memberikan penilaian yang baik, yaitu sesuai dengan harapan para guru dan mendapatkan bintang empat serta vidio lucu dari sekolah. Jika anak dirasa kurang dalam implementasi kreativitas seni, maka penilaian yang diberikan termasuk kurang mencapai standar perkembangan, artinya anak mendapatkan bintang dua dan para guru selalu mengontrol dan membimbing anak secara khusus mealui Video Call setiap mingguannya.

Para guru menilai pembelajaran seni rupa ini dari beberapa aspek perkembangan anak. Guru menilai anak dari kegiatan yang mereka lakukan. Para guru menilai dari aspek estetik atau keindahan karya seni, teknik anak dalam memahami perintah orang tua, teknik memberikan warna dan cara mewarnai dengan baik. Selain hal tersebut, para guru juga melakukan penilaian sensoris motorik, kognitif, sosial emosional anak saat mereka melakukan kegiatan pembelajaran. Para guru juga ikut mewawancarai dan berdiskusi mengenai keadaan, peningkatan, serta kendala anak kepada orangtua. Jika anak dirasa kurang dalam implementasi pembelajaran seni ini, maka kendalanya ada pada kurangnya bimbingan orangtua. Tindakan guru adalah membuat bimbingan khusus melalui Video Call dan memberikan media pembelajaran kepada anak untuk dikerjakan kembali dengan baik. Hal ini tentunya membutuhkan bimbingan dan arahan dari orangtua. Kepala sekolah bertanggung jawab untuk memberikan pengarahan kepada orangtua agar mereka medampingi anak saat pembelajaran dilakukan.

\section{Pembahasan}

Perencanaan Kegiatan Pembelajaran kreatif Seni Rupa Anak PAUD

Pada dasarnya saat ingin melakukan sebuah pembelajaran seni maka dibutuhkan sebuah pengelolaan dalam merencanakannya. Berbagai penelitian menjelaskan bahwa jika ingin mengajarkan pembelajaran seni kepada anak didik, maka hal yang paling utama adalah merencanakan, mengorganisir, melaksanakan, dan mengevaluasi pembelajaran berdasarkan kurikulum berkompetensi dengan adanya jadwal pembelajaran yang kreatif, inovatif serta kalender akademik menjadi dasar dari implementasi pembelajaran (Suhaedin \& Giri, 2016). Implementasi kegiatan pembelajaran seni rupa di RA Masyithoh Rembang juga menggunakan sebuah pedoman kurikulum berkompetensi tanggap darurat yang digunakan saat pandemi covid-19. Para guru juga membuat sebuah rancangan kegiatan pada setiap tahun, semester, mingguan, dan harian agar kegiatan seni dapat terealisasikan dengan baik.

Perencanaan pada sesi kali ini diperuntukkan pada pembelajaran berbasis daring bagi anak PAUD. Pembelajaran daring merupakan pembelajaran jarak jauh yang dipersiapkan oleh guru melalui berbagai perencanaan yang memadai serta fasilitas yang baik bagi anak didik (Ayuni \& Marini, 2021). Pembelajaran kreatif seni yang diajarkan pada pembelajaran seni rupa di RA Masyithoh Rembang saat pandemi menggunakan sebuah perencanaan yang baik, diantaranya berdasarkan Program Tahuan, Semester, Minguan dan Harian. Seluruh perencanaan silabus tersebut diaplikasikan kepada anak-anak berdasarkan tema yang menarik. Penelitian mengungkapkan bahwa penggunaan pembelajaran yang tematik sangat dianjurkan bagi guruguru PAUD. Para guru harus memahami 
pembelajaran tematik dengan baik, dikarenakan pembelajaran tematik manjadi salah satu pembelajaran yang dapat diaplikasikan berdasarkan pendekatan holistik integratif yang berpusat pada anak didik melalui perencanaan, pelaksanaan, dan penilaian (Apriyanti, 2017; Wulandari \& Suryatna, 2017).

\section{Implementasi Pelaksanaan Kegiatan Pembelajaran kreatif Seni Rupa pada PA- UD}

Pembelajaran kreatif seni yang diimplementasikan kepada peserta didik hendaknya memiliki unsur estetika yang dapat diapresiasikan menjadi sebuah karya seni yang menarik dan kreatif yang dapat dibuat dari bahan di sekitar lingkungan peserta didik. Setelah diterapkannya unsur tersebut, maka karya seni harus dinilai sebagai tolak ukur dalam estetikanya (Suhaedin \& Giri, 2016). Pendidikan seni yang diimplementasikan oleh guru dalam pembelajaran seni rupa berbasis daring di RA Masyhitoh ini dilakukan berdasarkan unsur yang telah disebutkan. Pembelajaran kreatif seni rupa di lembaga RA sudah menggunakan unsur estetika sebagai pedoman dalam penerapannya. Adanya kegiatan kreatif seni berupa melukis dan mewarnai, kreasi membuat wayang domba, kreasi ikan dari botol, kreasi kaca mata dari botol air mineral, membentuk rumah dari plastisin, membentuk dan merangkai bentuk ulat dari kertas origami.

Pembelajaran seni rupa anak usia dini di RA Masyithoh menggunakan unsur seni rupa dua dimensi dan tiga dimensi. Kreasi seni rupa dua dimensi diterapkan di RA dalam bentuk kegiatan mewarnai gambar dan melukis. Kreasi seni rupa berbentuk tiga dimensi diterapkan berbentuk kegiatan membuat wayang dari kapas, membuat keasi ikan dari tutup botol, membuat bentuk rumah dari plastisin dan membuat kreasi ikan dari kertas origami.

Guru memberikan arahan kepada orangtua saat pembelajaran seni akan dimulai seca- ra daring. Pembelajaran daring dapat diimplementasikan melalui penggunaan media sosial seperti facebook, WhatsApp group dan Vidio Call. Pembelajaaran seni di RA menggunakan media Facebook, youtube, WhatsApp Group serta Vidio Call dalam pelaksanaan pembelajarannya. Sebuah penelitian menyatakan bahwa pembelajaran di era pandemi harus mengandung unsur menarik, inovatif, serta dapat bermafaat bagi pertumbuhan dan perkembangan anak didik (Faila, 2020). Pembelajaran kreatif seni rupa pada anak usia dini di RA Masyithoh Rembang mengandung unsur kreatif dan inovatif. Adanya kegiatan yang menarik bagi anak dapat membuat anak senang dan tidak bosan saat pengimplementasian pmbelajaran dari rumah. Pembelajaran di RA Masyithoh didesain berdasarkan kebutuhan dan minat anak agar aspek perkembangan anak dapat berkembang dengan baik. Hal ini tentunya ada suatu kerjasama yang baik dari orangtua, guru dan anak agar pendidikan seni dalam pembelajaran seni rupa anak dapat meningkat sesuai dengan harapan.

Pendidikan seni rupa memiliki sebuah tujuan yang holistik integratif bagi pertumbuhan dan perkembangan anak, terkhusus anak usia dini. Studi penelitian menyatakan bahwa adanya pelaksanaan kegiatan pembelajaran kreatif seni bagi anak usia dini di lembaga PAUD memiliki tujuan agar aspek perkembangan anak dapat berkembang dengan baik. Adapun aspek perkembangan yang dapat terealisasikan dengan baik dapat berupa perkembangan sosial, emosional, inetelektual, bahasa atau linguistik, motorik halus dan kreativitas seni estetika anak usia dini (Anhusadar, 2016). Dalam pengimplementasiannya, kegiatan kreatif seni rupa yang dilaksanakan melalui metode daring ini memiliki banyak tujuan dalam penerapannya kepada anakanak RA Masyithoh Rembang. Tujuan yang mendasar adalah kegiatan ini dapat mengembangkan tingkat berfikir kreatif anak serta ke- 
mandirian anak saat mengerjakan tugas kreasi seni. Tujuan yang lainnya adalah dapat mengembangkan aspek linguistik anak dengan membuat kreasi seni kemudian menceritakannya sesuai dengan imajinasi anak.

Studi penelitian pendidikan anak usia dini yang bertemakan bercerita dengan kreasi wayang seperti yang tertera pada tujuan implementasi kreativitas seni di RA Masyithoh Rembang menegaskan bahwa jika para guru ataupun orangtua ingin mengembangkan aspek bahasa atau linguistik anak, maka para guru dapat menggunakan media yang berbentuk wayang yang terbuat dari kertas. Wayang ini dapat dibuat sendiri oleh anak atau wayang ini sudah tersedia sebagai media bercerita anak (Handayani \& Wirya, 2016). Penelitian mengungkapkan bahwa kegiatan pembuatan kreasi wayang merupakan salah satu kegiatan yang dapat menumbuhkan karakter baik dalam diri anak, serta menumbuhkan imajinasi anak kreatif dalam diri anak didik (Mahenra \& Sunarta, 2017). Adanya penelitian tersebut maka, kegiatan kreasi wayang domba ini sangat penting diaplikasikan kepada anak sebagai pengembang bahasa atau linguistik anak, karakter anak, aspek kemandirian, emosional, agama, dan kreativitas anak di bidang seni rupa tiga dimensi.

Kegiatan seni mewarnai dan melukis saat pandemi covid di RA Masyithoh diimpementasikan berdasarkan arahan guru berupa contoh pola gambar yang sudah disediakan. Tugas anak hanya memberikan warna sesuka hati mereka. tujuannya adalah agar anak dapat bereksperimen melalui berbagai warna sesuai dengan emosionalnya. Pendapat ini dikuatkan dengan adanya sebuah penelitian yang menyatakan bahwa adanya strategi pemberian contoh pola gambar pada anak usia dini dapat mempermudah anak untuk berkreasi warna sesuai dengan pola yang telah ditetapkan. Tujuan utamanya adalah agar para guru dapat mengethaui tingkat kreativitas anak dalam mewarnai gambar serta emo- sional yang mereka terapkan dalam gambar (Retnowati, 2009).

Selain kegiatan yang telah disebutkan, ada jenis kegiatan kreativitas seni rupa yang menggunakan bahan barang bekas, seperti tutup botol bekas ataupun botol air mineral gelas bekas. Suatu penelitian menyebutkan bahwa penggunaan barang bekas dalam pembuatan karya seni pada anak dapat meningkatkan kreativitas anak dengan sendirinya. Anak dapat belajar akan kegunaan barang bekas jika didaur ulang menjadi sebuah karya seni yang dapat dipakai, seperti mainan edukatif anak. selain hal tersebut, anak juga dapat belajar untuk mengembangkan motorik, imajinasi dan kognitif sebagai tingkat berfikir anak dalam membuat karya seni dari barang bekas (Agustina, 2019). Studi penelitian lain mengungkapkan jika ada pembelajaran kreatif seni yang berbahan dasar barang bekas maka dapat disimpulkan bahwa pembelajaran seni tersebut dapat dikatakan menarik. Hal ini dikarenakan pada saat anak membuat karya seni melalui barang bekas, maka anak akan melalui proses tahap dalam pembuatan produk. Anak dapat belajar mengenai kesabaran, keuletan dalam membuat produk dari barang bekas (Hanafi \& Sujarwo, 2015). Seperti halnya anak di RA Masyithoh yang membuat karya seni rupa kacamata dari barang bekas. Anak dapat belajar mengenai kesabaran dalam menggunting dan menempel pola dasar dalam membuat kreasi kacamata dari air mineral gelas. Secara umum, pelaksanaan kreasi seni rupa yang dilakukan bersifat open-ended untuk memungkinkan dan memberi ruang pada inovasi siswa (Wulandari, 2020).

\section{Implementasi Evaluasi Kegiatan Pembel- ajaran kreatif Seni Rupa PAUD}

Kegiatan evaluasi dalam pembelajaran sangat diperlukan untuk dilakukan. Evaluasi dalam pembelajaran bertujuan sebagai tolak ukur dalam menilai keberhasilan belajar anak. Pada sesi kali ini para guru hendaknya 
menyiapkan kegiatan yang akan dinilai. Selanjutnya adalah para guru menetapkan alat untuk menilai serta menetapkan kriteria penilaian yang akan digunakan (Jatmiko et al., 2020). Penilaian juga dilakukan guna mengetahui informasi dari tingkat perkembangan anak yang diketahui dari kegiatan-kegiatan yang guru lakukan kepada anak didik (Iftitah, 2019, p. 1-2). Pembelajaran seni yang diterapkan di RA Masyithoh Rembang menggunakan kriteria penilaian yang berkategori BSB yang artinya Berkembang Sangat Baik dan BB yang artinya Belum Berkembang. Jika kategori BSB maka, hasil karya anak sangat baik dan mencapai perkembangan yang meningkat. Jika anak dirasa kurang dalam pengimplementasian kegiatan kreasi, maka dapat diberikan nilai belum berkembang dan ini harus ada pengulangan serta bimbingan dari orangtua. Adanya anak yang mendapatkan penilaian rendah diarenakan kurangnya bimbingan dari orangtua secara langsung.

Pembelajaran seni daring yang diterapkan di RA memiliki kendala dalam pengimplementasiannya, di antaranya kurangnya kekuatan sinyal dikarenakan hujan di wilayah Rembang, kurang adanya kekuatan kapasitas memori pada Handphone yang pada akhirnya para guru membeli alat komunikasi yang baru sebagai alat bantu pembelajaran daring. Jika kapasitas daya tingkat media sosial yang tidak baik, maka hal ini berpengaruh pada pemahaman anak. Guru tidak dapat leluasa dalam membimbing dan memantau tingkat perkembangan anak. Studi penelitian mengungkapkan bahwa kendala yang digambarkan pada sesi di atas, dapat dikategorikan dengan kendala yang berunsur komunikasi melalui media sosial. Ada beberapa indikator yang berpengaruh pada kurangnya peningkatan pemahaman pembelajaran bagi anak didik. Hal ini didapat dari adanya indikator yang dialami guru seperti kendala komunikasi, metode pembelajaran, materi yang disampaikan dan biaya pembelajaran akibat adanya penambahan data kuota internet dalam melakukan pembelajaran daring (Agustin \& Puspita, 2021).

Adanya kendala tersebut, maka haruslah ada suatu strategi untuk penanganan dan penanggulangan permasalahan pembelajaran saat daring. Adanya strategi pngimplementasian pembelajaran yang santai, menyenangkan dan sesuai dengan kebutuhan membuat pembelajaran dapat berjalanan dengan efektif dan efesien walaupun pembelajaran dilakukan saat daring (Yuangga \& Sunarsi, 2020). Selain adanya hal tersebut pemberian motivasi belajar pada anak usia dini dapat diterapkan oleh guru agar perkembangan anak dapat meningkat dengan baik. Para guru dapat mengimplementasikan motivasi ini dengan pemberian pesan teks singkat yang berunsur kesenangan (Suhendro, 2020). Hal ini juga diimplementasikan ke dalam strategi pembelajaran kreatif seni rupa bagi anak usia dini di RA Masyithoh Rembang. Para guru mengapreasisasi seluruh karya anak denangan apreasi menyenangkan. Para guru memberikan senyuman, pesan singkat dengan emoticon lu$\mathrm{cu}$, sanjungan dan motivasi agar anak senang terhadap karya yang diciptakannya. Jika para anak-anak belum mencapai aspek perkembangan terhadap kreativitas seni anak, maka guru mengadakan bimbingan belajar secara serentak melalui Vidio Call saat kegiatan pembelajaran semester telah selesai

\section{KESIMPULAN}

Kegiatan pembelajaran kreatif seni rupa anak usia dini yang diterapkan di RA Masyithoh Rembang memiliki beberapa konsep implementasiannya. Adanya suatu perencanaan yang melibatkan silabus pembelajaran meliputi program tahunan, semester, mingguan, dan harian. Adanya suatu perencanaan berupa penyerahan media dan arahan dari guru dan orangtua dalam mengimplementasikan kegiatan kreativitas seni bagi anak di rumah. Hal ini diterapkan guna membangun 
komunikasi dan kerjasama antara guru dan orang tua dalam membimbing anak untuk mengerjakan kreatvitas seni rupa di rumah. Adapun pelaksanaannya dapat melalui video dan dokumentasi foto dari orangt ua kemudian dikirimkan kepada guru wali kelas untuk diunggah di media sosial Facebook dan youtube. Adapun jenis kegiatan kreativitas seni yang dapat membuat anak berkembang adalah kegiatan membuat wayang binatang, kreasi ikan dari tutup botol, bentuk ulat dari kertas origami, kolase lebah dari biji-bijian, kreasi rumah dari plastisin, bentuk kacamata dari barang bekas, dan ekstrakulikuler mewarnai dan melukis. Adapun semua kegiatan tersebut dilakukan oleh anak dengan bantuan bimbingan orangtua. Adapun evaluasi dari implementasi kegiatan seni ini adalah melalui kegiatan ini dapat melatih anak untuk menghargai diri sendiri, menghargai karya yang mereka ciptakan, mengembangkan aspek kognitif, sensorimotorik, bakat dan kreativitas anak. disamping itu pula anak akan belajar akan estetika karya seni yang dapat diterapan melalui imaji bercerita. Penilaian yang didapat adalah sebagian besar anak dapat menerapkannya di rumah dengan apresiasi karya seni yang baik berkategori berkembang Sangat Baik dan berkembang sesuai harapan.

\section{DAFTAR PUSTAKA}

Agustin, M., \& Puspita, R. D. (2021). Tipikal Kendala Guru PAUD dalam Mengajar pada Masa Pandemi Covid 19 dan Implikasinya. Jurnal Obsesi : Jurnal Pendidikan Anak Usia Dini, 5(1), 334-345. https://doi.org/10.31004/obsesi. v5i1.598

Agustina, R. (2019). Pemanfaatan Barang Bekas Sebagai Media Peningkatan Kreativitas Pada Mata Pelajaran SBK. Joyful Learning Journal, 7(3), 75-79. https://doi.org/https://doi.org/10.15294/jlj. v7i3.25859
Anhusadar, L. (2016). KREATIVITAS PENDIDIK DI LEMBAGA PAUD. $A l-$ Ta'dib: Kajian Ilmu Penidikan, 9(1), 76-93.

Apriyanti, H. (2017). Pemahaman Guru Pendidikan Anak Usia Dini Terhadap Perencanaan Pembelajaran Tematik. Jurnal Obsesi : Jurnal Pendidikan Anak Usia Dini,1(2),111-117.https://doi. org/10.31004/obsesi.v1i2.22

Astuti, E. P., Suardana, I. W., Ambarwati, D. R. S., Wulandari, D., \& Isa, B. (2021). Teachers' Perceptions of Museum-Based Learning and Its Effects on Creativity: A Preliminary Study. Proceedings of the 4th International Conference on Arts and Arts Education (ICAAE 2020), 552(ICAAE 2020), 215-221. https:// doi.org/10.2991/assehr.k.210602.043

Ayuni, D., \& Marini, T. (2021). Kesiapan Guru TK Menghadapi Pembelajaran Daring Masa Pandemi Covid-19. Obsesi Jurnal Pendidikan Anak Usia Dini, 5(1), 414-421.https://doi.org/https://doi. org/10.31004/obsesi.v5i1.579

Betiani, R. (2020). Dampak Pembelajaran Daring (Online) bagi Anak Usia Dini. Kompasiana.Com.

Fadlillah. (2014). Edutainment Pendidikan Anak Usia Dini: Menciptakan Pembelajaran Menarik, Kreatif dan Menyenangkan (Pertama). Kencana Prenamedia Group.

Faila, S. (2020). Inovasi Pembelajaran Pada Pendidikan Anak Usia Dini di Masa Pndemi Covid 19. Jurnal Buana Gender, 5(2), 1-12. https://doi.org/10.22515/bg. v5i2. 2820

Fakhruddin, A. U. (2019). Menjadi Guru Pa$u d$. PT Alex Media Komputindo.

Hanafi, S. H., \& Sujarwo, S. (2015). Upaya meningkatkan kreativitas anak dengan memanfaatkan media barang bekas di TK Kota Bima. Jurnal Pendidikan Dan Pemberdayaan Masyarakat, 2(2), 215- 
225.https://doi.org/10.21831/jppm. v2i2.6360

Handayani, W. K., \& Wirya, N. (2016). Penerapan Metode Bercerita Berbantu Media Wayang Kertas Untuk Meningkatkan Kemampuan Bahasa Anak Kelompok A. Jurnal Pendidikan Anak Usia Din Undhiksa, 4(2), 1-11. https://doi.org/http://dx.doi.org/10.23887/paud. v4i2.7792

Hidayah, C. N. (2020). MENUMBUHKAN KECERDASAN EMOSIONALPADA ANAK USIA DINI MELALUI KESENIAN. Jurnal Pelita PAUD, 4(2), 269. https://doi.org/https://doi.org/10.33222/ pelitapaud.v4i2.987

I.Bagus. (2020). Analisis Gambar Karya Anak Usia Dini. Jurnal Ilmu Pendidikan, 5(1), 43-51. https://doi.org/http:// dx.doi.org/10.25078/pw.v5i1.1358

Iftitah, S. L. (2019). Evaluasi Pembelajaran Anak Usia Dini. Duta Media Publshing.

Jatmiko, A., Hadiati, E., \& Oktavia, M. (2020). Penerapan Evaluasi Pembelajaran Anak Usia Dini di Taman Kanak-kanak. Al-Athfaal: Jurnal Ilmiah Pendidikan Anak Usia Dini, 3(1), 83-97.https://doi. org/10.24042/ajipaud.v3i1.6875

Khadijah \& Gusman. (2020). POLA KERJA SAMA GURU DAN ORANGTUA MENGELOLA BERMAIN AUD SELAMA MASA PANDEMI COVID-19. Jurnal Kumara Cendekia: Jurnal Penelitian Pendidikan Anak Usia Dini, 8(2). https://doi.org/https://doi.org/10.20961/ kc.v8i2.41871

Mahenra, K., \& Sunarta, K. (2017). Peningkatan Apreasiasi dan Kreativitas Siswa SD Negeri Timuran Yogyakarta Pada Pembelajaran Seni Budaya dan Keterampilan (Seni Rupa) Menggunakan Menggunakan Media Wayang Punokawan. Jurnal Imaji Pendidikan Seni, 15(2). https://doi.org/DOI: https://doi. org/10.21831/imaji.v15i2.15045
Menteri Pendidikan dan Kebudayaan RI. (2020). Pelaksanaan Kebijakan Pendidikan Dalam Masa Darurat Penyebara Corona Virus Disease (Covid 19) (No. 4).

Rapisa, D. R. (2019). Program Latihan Koordinasi Sensomotorik Bagi Anak Usia Dini Dan Anak Usia Dini dan Anak Berkebutuhan Khusus. Deepublish.

Retnowati, T. H. (2009). Strategi Pembelajaran Seni Lukis Anak Usia Dini Di Sanggar Pratista Yogyakarta. Imaji, 7(2), 202-214. https://doi.org/10.21831/imaji.v7i2.6636

Santaria, R., \& Setiawan, E. I. (2020). Tantangan Pembelajaran Daring Di Indonesia. Manajemen Pendidikan Islam, 5(2), 89-98.https://doi.org/https://doi. org/10.24256/kelola.v5i2.1397

Sarasehan, Y. (2020). Pengembangan Seni Rupa Tiga Dimensi Untuk. Jurnal Nanaeke Indonesian Journal of Early Childhood Education, 3(March 2019), 28-36. https://doi.org/https://doi.org/10.24252/ nananeke.v3i1.13557

Sugiyono. (2014). Metode Penelitian Kuantitatif, Kualitatif, dan Kombinasi (Mixed Method). Alfabeta.

Suhaedin, E., \& Giri, P. (2016a). Empat Pilar Perubahan Paradigma Pendidikan Seni. Jurnal Imaji Pendidikan Seni, 14(1). https://doi.org/DOI:https://doi. org/10.21831/imaji.v14i1.9529

Suhaedin, E., \& Giri, P. (2016b). EMPAT PILAR PERUBAHAN PARADIGMA PENDIDIKAN SENI. Jurnal Imaji, 14(1). https://doi.org/DOI: https://doi. org/10.21831/imaji.v14i1.9529

Suhendro, E. (2020). Strategi Pembelajaran Pendidikan Anak Usia Dini di Masa Pandemi Covid-19. Jurnal Ilmiah Tumbuh Kembang Anak Usia Din, 5(3), 1-8. https://doi.org/DOI:https://doi. org/10.14421/jga.2020.53-05 
Susanto, A. (2020). Ruang Guru PAUD Kementerian Pendidikan dan Kebudayaan: Selama Pandemi Covid-19, Guru PAUD Harus Kreatif. Kemdikbud. Go.Id.

Wibowo, D. V., \& Suyadi. (2020). Kegiatan Kreativitas Seni Warna Anak Usia Dini Melalui Permainan Cat Air di Masa Pandemi. PAUD Lectura: Jurnal Pendidikan Anak Anak Dini, 4(1), 74-87. https:// doi.org/10.31849/paud-lectura.v

Wulandari, D. (2020). Advantages and challenges of the open-ended approach in nurturing creativity. 21 st Century Innovation in Music Education, 468-474.

Wulandari, D., \& Suryatna, A. (2017). The Role of Arts Education in Fostering Creative Problem Solving Skills and Its Implementation in Curriculum 2013. The International Seminar QUOVADIS of Traditional Arts XIII "Diversity in Culture."
Yuangga, K. D., \& Sunarsi, D. (2020). Pengembangan media dan strategi pembelajaran untuk mengatasi permasalahan pembelajaran jarak jauh di pandemi covid- 19. Jurnal Guru Kita, 4(3), 51-58.

Yulianingsih, W. (2021). Keterlibatan Orangtua dalam Pendampingan Belajar Anak selama Masa Pandemi Covid-19. Jurnal Obsesi : Journal of Early Childhood Education, 5(2), 1138-1150. https://doi. org/: 10.31004/obsesi.v5i2.740

Yuningsih, C. R. (2019). Pembelajaran Seni Rupa Di Pendidikan Anak Usia Dini. Jurnal Edukasi Sebelas April, 3(1), 1-7. 